2021-02-04

\title{
Mobile apps for self-management in pregnancy: a systematic review
}

lyawa, GE

http://hdl.handle.net/10026.1/18665

10.1007/s12553-021-00523-z

Health and Technology

Springer (part of Springer Nature)

All content in PEARL is protected by copyright law. Author manuscripts are made available in accordance with publisher policies. Please cite only the published version using the details provided on the item record or document. In the absence of an open licence (e.g. Creative Commons), permissions for further reuse of content should be sought from the publisher or author. 


\title{
Mobile Apps for Self-Management in Pregnancy: A Systematic Review
}

\begin{abstract}
Complications during pregnancy is a major problem affecting healthcare systems which requires the efforts of both patients and healthcare practitioners. For this reason, mobile apps have been increasingly sought to support self-management during pregnancy. Although many benefits have been claimed for the inclusion of self-management mobile apps in supporting care, the domains already explored, functionalities and impacts of mobile apps for self-management in pregnancy is still not clear. A clear understanding of the health domains already explored, functionalities of existing apps which have been evaluated as well as the effectiveness of these apps can help researchers and health practitioners identify areas of future needs for self-management mobile apps during pregnancy. The objective of this systematic review was to provide a narrative synthesis of the literature on the evaluation of mobile apps for self-management during pregnancy. The search was conducted on four databases: PubMed, CINAHL, Scopus and EMBASE. 18 articles met the inclusion criteria. Nine randomised controlled trials (RCTs), one non-randomised controlled trial (NRCT) and eight observation studies evaluating self-management mobile apps among pregnant women were identified. Mobile apps for self-management have been developed with different functionalities addressing various areas of complications during pregnancy including gestational diabetes, preeclampsia and high blood pressure. These apps have also been evaluated in countries mostly in the developed context. We conclude that there have been positive impacts of mobile apps for self-management during pregnancy; however, future research should focus on evaluation studies of mobile apps for selfmanagement during pregnancy within developing countries as well as the use of mobile apps for the identification of sexually transmitted infections, early warning signs of potential still birth, miscarriage and management of anaemia during pregnancy.
\end{abstract}

Keywords: Mobile apps; pregnancy; self-management; complications; monitoring.

\section{Introduction}

While there has been a rapid decline in maternal mortality since 2000 , many regions in the world still experience high maternal mortality rates [1]. 86\% of global maternal deaths occur in sub-Saharan African and South Asian countries [1]. Preeclampsia, preterm labour and gestational diabetes are common complications that occur during pregnancy [2]. The World Health Organisation (WHO) recommends accessible quality healthcare services as a means to prevent 
complications during pregnancy [3]. This could be achieved when pregnant women regularly visit the hospital and inform the doctor when danger signs are noticed. However, due to challenges such as lack of health facilities in rural communities and a dearth of skilled medical practitioners, it is often impractical for pregnant women to receive high quality care during pregnancy [3]. Furthermore, most pregnant women are not aware of danger signs and techniques to improve care during pregnancy [3].

Self-management is described as engaging in activities that promote good health [4]. Self-management can be useful in supporting pregnant women. Iyawa, Herselman and Botha [5] emphasise that digital health allow patients engage with their health through the use of digital technologies. Iyawa, Botha and Herselman [6] further highlight the different components of digital health that facilitate self-care which include mobile technologies, wearable and sensor technologies.

Mobile health (mHealth) is described as "the use of any mobile device including mobile phones, smartphones, mobile or phone-based sensors for providing and receiving healthcare services such as healthcare monitoring, diagnosis, management and prediction of diseases" [7]. Components such as microphone, camera, GPS, and accelerometer represents sensors in mobile phones [8]. These components are often used to sense activities in the environment as well as determine points and locations [8]. Mobile phone sensors have also been used for healthcare purposes. For example, Statland et al. [9] explored microphone as a diagnostic tool to classify symptoms of myotonic syndrome.

Recent advances in mobile technologies have explored the use of technologies in self-management to support diseases such as asthma [10] and diabetes [11]. The use of mHealth for healthcare services has led to low-cost healthcare solutions especially for people living in rural communities, which includes diagnosis and monitoring of patients' health [12]. Different studies have evaluated the effectiveness of self-management mobile apps [13] [14]. For example, Whitehead and Seaton [14] conducted a systematic review on the effectiveness of selfmanagement apps on long term diseases. The study found that self-management apps had a positive effect on health outcomes. A quantitative analysis of the literature suggests that mHealth apps have been significant in improving weight management and control symptoms such as diabetes and asthma during pregnancy [15]. mHealth has also facilitated antenatal and postnatal care in developing countries [16]. While there is an increase in published studies on mHealth applications for managing pregnancies [15] [16], there is a need to also identify which health domains have been supported by self-management apps in the literature, the effectiveness of these apps and their functionalities. Thus, in this paper, our objective was to conduct a systematic review of empirical literature on mobile apps for self-management during pregnancy with the aim of (1) identifying the different self-management mobile apps 
which have been developed and evaluated to support women during pregnancy, (2) identifying the functionalities of self-management mobile apps for pregnancy, (3) describing the effectiveness of self-management mobile apps for pregnancy and (4) identifying the research gaps in the current literature and suggesting directions for future research. A clear understanding of the functionalities of apps which have been evaluated as well as the effects of these apps can help researchers and practitioners identify areas of future needs for self-management mobile apps during pregnancy, new areas to address and the effectiveness of existing apps. This paper contributes to the ongoing research on self-management mobile apps for pregnancy and serves as a reference to researchers conducting research in this domain on the current trends on self-management mobile apps for pregnancy and what future needs are required in this domain.

This paper is structured as follows: Section 2 describes the materials and methods used in this study. Section 3 presents the findings. Section 4 and Section 5 provide the discussion and concludes the study.

\section{Materials and Methods}

A systematic review approach was adopted in this study. The study followed the principles of the Preferred Items for Systematic Reviews and Meta-Analyses (PRISMA) [17].

Studies were selected based on the following inclusion and exclusion criteria:

\section{Inclusion criteria}

- Studies which clearly indicated that the participants were pregnant

- Studies which had either feasibility assessment, pilot testing or evaluation of a mobile app

- Studies in which participants were directly involved in the use of the app

- Studies focused on evaluating health outcomes during pregnancy

- Studies published in English

- Peer-reviewed journal articles and conference papers

\section{Exclusion criteria}

- Studies not related to health outcomes

- Studies on mobile app development with no evaluation or intervention

- Study protocols were removed

- Letters, comments, abstracts and non-peer reviewed papers were removed

- Reviews and systematic reviews were removed.

\section{Data Sources and Search Strategy}


We searched PubMed, Scopus, CINAHL and EMBASE. The search strategy for each database is presented in Appendix 1. The search period was between 2009 to 2019.

\section{Data Extraction}

Titles were initially screened after which the abstracts were screened to identify relevant papers. Fulltext papers with relevant abstracts were downloaded. For each fulltext paper, author details, year of publication, country, study design, domain, study characteristics, intervention description and outcome were extracted (Table I). The study design for the papers retrieved in this study were categorised based on four types as indicated in the University of California San Francisco-Stanford Evidence-Based Practice Centre framework [18]: Randomised Control Trial (RCT), Non-randomised controlled trial (NRCT), observational studies with controls (OWC) and observational studies without control [18].

\section{Data Synthesis}

A narrative synthesis of the findings was presented. To assess the health domain and functionality of the app, each app identified in each paper was categorised into the following areas: inform, instruct, record, display, guide, remind/alert and communicate based on the components recommended by [19]. Other studies have also applied this approach to assess app functionalities [39].

\section{Results}

In total, 1891 studies were included in this study (Figure I). 28 duplicate papers were removed. The remaining 1863 papers were screened based on the title and abstract relevance, 371 fulltext papers were examined in which 18 papers met the inclusion criteria. 

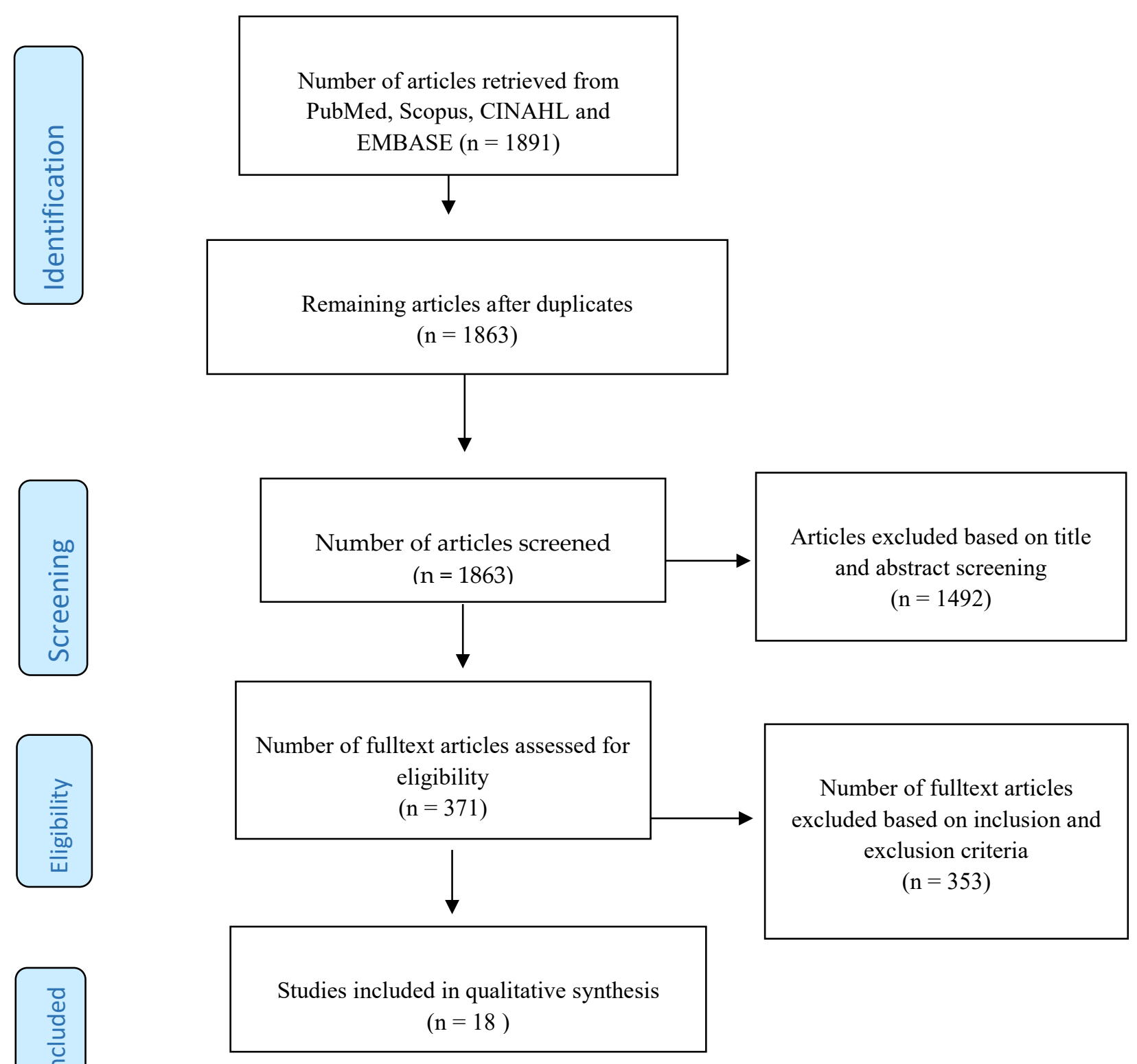

Number of fulltext articles excluded based on inclusion and exclusion criteria $(\mathrm{n}=353)$

\section{Figure I: Included papers adopted from [17]}

\section{Characterisitcs of Included Studies}

Based on the summary in Table I, a total of 7 studies emanated from the United States (7/18), 2 studies emanated from Norway (2/18), 1 study emanated each from Brazil, Singapore, China, Denmark, the United Kingdom, Australia, Ireland, Iran and Switzerland. 6 studies were publsihed in 2019, 6 studies were published in 2018, 4 studies were published in 2017 and 2 studies were publsihed in 2016. The sample size for participants ranged from 8 to 565 . Various study designs were applied including RCT (9/18), NRCT (1/18) and observation studies without control (8/18). 


\section{Domain}

Different health domains were identified in the study. A majority $(3 / 18)$ of the studies identfied focused on gestational diabtes/mellitus and (3/18) nutrition and physcial activity. Some studies (2/18) focused on blood pressure and weight management weight management and (2/18) focused on depression. The other studies $(1 / 18)$ each focused on blood pressure, pregnancy development, smoking cessation, gestational weight gain, blood glucose and weight management, preexisting diabetes, preclampsia and pregnancy risks. The domains which have been used in the study are illustrated in Figure II.

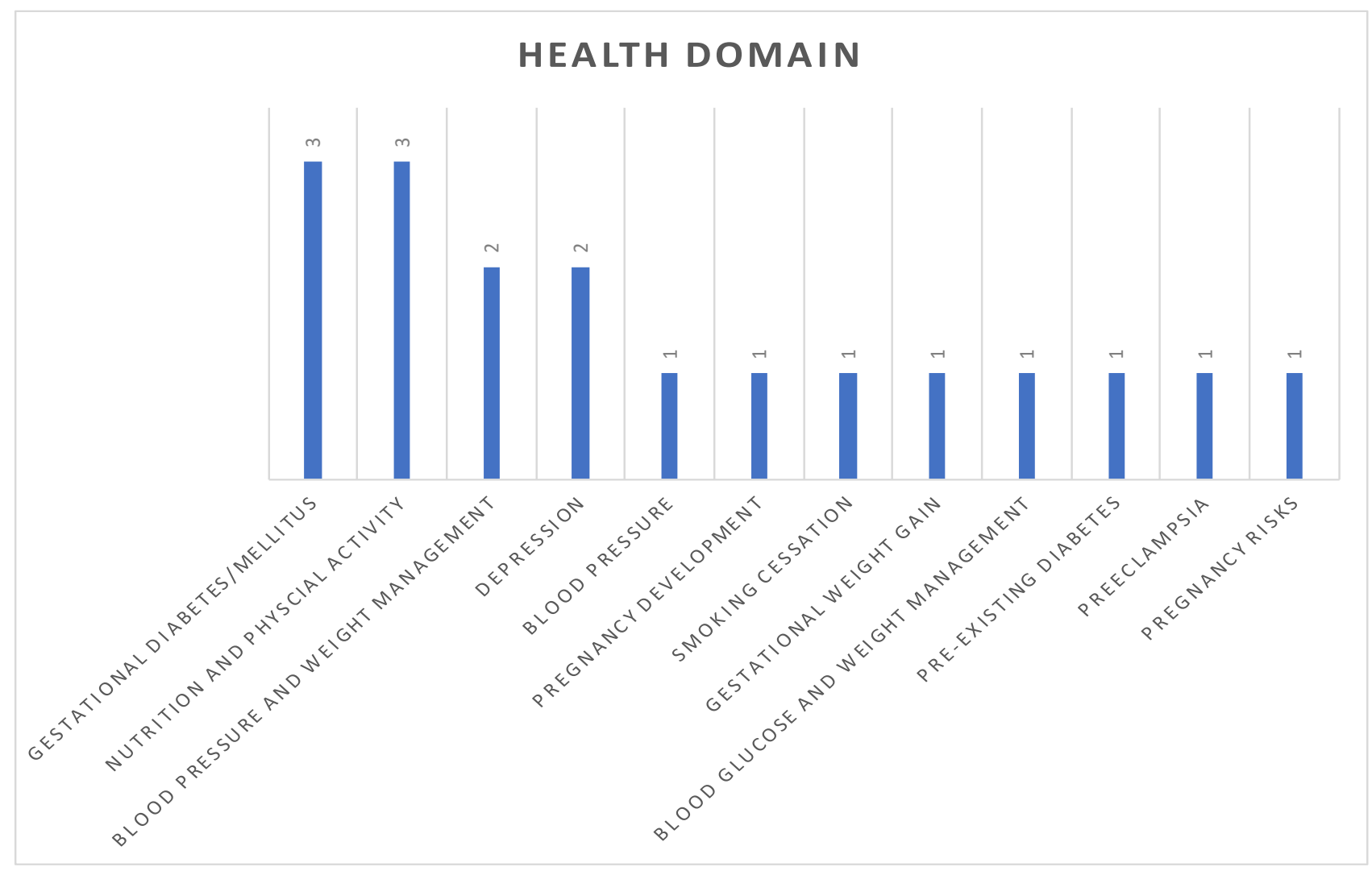

Figure II: Health domain 


\begin{tabular}{|c|c|c|c|c|c|c|c|}
\hline Author & Year & Country & Study Design & Domain & $\begin{array}{l}\text { Study } \\
\text { characteristics }\end{array}$ & $\begin{array}{l}\text { Intervention } \\
\text { description }\end{array}$ & Outcomes \\
\hline [20] & 2019 & Brazil & $\begin{array}{l}\text { Observation } \\
\text { study without } \\
\text { control }\end{array}$ & $\begin{array}{l}\text { Pregnancy } \\
\text { development }\end{array}$ & $\begin{array}{l}13 \text { pregnant } \\
\text { women were } \\
\text { included in the } \\
\text { study. The study } \\
\text { duration is } 5 \\
\text { months }\end{array}$ & $\begin{array}{l}\text { The mobile app - } \\
\text { GestAção was } \\
\text { developed for women } \\
\text { to participate in self- } \\
\text { management } \\
\text { activities to monitor } \\
\text { pregnancy } \\
\text { development }\end{array}$ & $\begin{array}{l}\text { Participants were } \\
\text { satisfied with the } \\
\text { app and it } \\
\text { improved their } \\
\text { knowledge on } \\
\text { pregnancy } \\
\text { development. The } \\
\text { app improved the } \\
\text { change of attitude } \\
\text { towards managing } \\
\text { pregnancy }\end{array}$ \\
\hline [21] & 2019 & Norway & RCT & $\begin{array}{l}\text { Gestational } \\
\text { diabetes }\end{array}$ & $\begin{array}{l}238 \text { pregnant } \\
\text { women were } \\
\text { randomly } \\
\text { selected to take } \\
\text { part in the study. }\end{array}$ & $\begin{array}{l}\text { The mobile app - } \\
\text { Pregnant+ } \\
\text { developed to allow } \\
\text { pregnant women } \\
\text { monitor their glucose } \\
\text { level, perform } \\
\text { physical activities, } \\
\text { eating healthy and } \\
\text { information about } \\
\text { diabetes. The } \\
\text { intervention was } \\
\text { divided into two } \\
\text { groups, group } \\
\text { intervention the }\end{array}$ & $\begin{array}{l}\text { The app did not } \\
\text { have any impact in } \\
\text { blood glucose } \\
\text { level. However, } \\
\text { there was an } \\
\text { impact } \\
\text { emergency care } \\
\text { and caesarean } \\
\text { birth as there were } \\
\text { reduced cases } \\
\text { identified in the } \\
\text { study }\end{array}$ \\
\hline
\end{tabular}




\begin{tabular}{|c|c|c|c|c|c|c|c|}
\hline & & & & & & $\begin{array}{l}\text { and the usual care } \\
\text { group. }\end{array}$ & \\
\hline [22] & 2019 & Singapore & RCT & $\begin{array}{l}\text { Gestational } \\
\text { weight gain }\end{array}$ & $\begin{array}{l}30 \text { pregnant } \\
\text { women were } \\
\text { randomly } \\
\text { selected to take } \\
\text { part in the study. } \\
\text { The women } \\
\text { either } \\
\text { overweight or } \\
\text { obese and older } \\
\text { than } 21 \text { years of } \\
\text { age. }\end{array}$ & $\begin{array}{l}\text { The mobile app - } \\
\text { Foodcoach was } \\
\text { developed to improve } \\
\text { the diet of type } 2 \\
\text { diabetic patients. } \\
\text { Women who took } \\
\text { part in the study were } \\
\text { able to take pictures } \\
\text { of their food and } \\
\text { upload it to the app, } \\
\text { after which advice } \\
\text { would be provided by } \\
\text { dieticians. The } \\
\text { intervention was } \\
\text { divided into two } \\
\text { groups, the } \\
\text { intervention group } \\
\text { and the control group. }\end{array}$ & $\begin{array}{l}\text { The findings } \\
\text { indicate that } \\
\text { pregnant women } \\
\text { who made use of } \\
\text { the app and were } \\
\text { allocated to the } \\
\text { intervention group } \\
\text { improved their } \\
\text { weight with lower } \\
\text { cholesterol levels } \\
\text { compared to } \\
\text { women in the } \\
\text { control group. }\end{array}$ \\
\hline [23] & 2019 & $\begin{array}{l}\text { United } \\
\text { States }\end{array}$ & NRCT & $\begin{array}{l}\text { Blood pressure } \\
\text { and } \\
\text { management }\end{array}$ & $\begin{array}{l}88 \text { pregnant } \\
\text { women were } \\
\text { included in the } \\
\text { study. }\end{array}$ & $\begin{array}{l}\text { The mobile app - } \\
\text { Babyscripts was } \\
\text { developed to educate } \\
\text { pregnant women on } \\
\text { how to control blood } \\
\text { pressure and how to } \\
\text { maintain a healthy } \\
\text { weight. The }\end{array}$ & $\begin{array}{l}\text { The findings } \\
\text { suggest that there } \\
\text { was a reduction of } \\
\text { inpatient visit } \\
\text { although one case } \\
\text { of still birth was } \\
\text { recorded and the } \\
\text { fetal haemorrhage }\end{array}$ \\
\hline
\end{tabular}




\begin{tabular}{|c|c|c|c|c|c|c|c|}
\hline & & & & & & $\begin{array}{|lr|}\text { participants } & \text { were } \\
\text { divided into } & \text { two } \\
\text { groups, } & \text { the } \\
\text { experimental group } & \text { and the control group }\end{array}$ & $\begin{array}{l}\text { was not caused as } \\
\text { a result of the } \\
\text { study. }\end{array}$ \\
\hline [24] & 2018 & $\begin{array}{l}\text { United } \\
\text { States }\end{array}$ & $\begin{array}{l}\text { Observation } \\
\text { study without } \\
\text { control }\end{array}$ & $\begin{array}{l}\text { Physical } \\
\text { activities }\end{array}$ & $\begin{array}{l}49 \text { women } \\
\text { participated } \\
\text { enrolled in study. } \\
\text { However, } 30 \\
\text { women } \\
\text { completed the } \\
\text { survey }\end{array}$ & $\begin{array}{l}\text { An activity tracking } \\
\text { device - wrist Fitbit } \\
\text { Flex }^{\mathrm{TM}} \text { as well as the } \\
\text { app were both } \\
\text { adopted in this study. } \\
\text { The activity tracking } \\
\text { device was used to } \\
\text { track activities of the } \\
\text { patients which was } \\
\text { later presented on a } \\
\text { graph through the } \\
\text { app. }\end{array}$ & $\begin{array}{l}\text { The findings } \\
\text { suggest that } \\
\text { activity tracking } \\
\text { devices during } \\
\text { pregnancy } \\
\text { improved } \\
\text { awareness of } \\
\text { women's activities } \\
\text { during pregnancy. }\end{array}$ \\
\hline [25] & 2019 & China & RCT & $\begin{array}{l}\text { Weight } \\
\text { management } \\
\text { and blood } \\
\text { glucose control }\end{array}$ & $\begin{array}{l}124 \text { women with } \\
\text { gestational } \\
\text { diabetes were } \\
\text { included in the } \\
\text { study. The trial } \\
\text { was conducted } \\
\text { over a period of } \\
13 \text { weeks }\end{array}$ & $\begin{array}{l}\text { A mobile app - } \\
\text { Dnurse was } \\
\text { developed to provide } \\
\text { a mechanism where } \\
\text { patients glucose } \\
\text { levels could be } \\
\text { measured by patients. } \\
\text { The data would then } \\
\text { be transmitted and } \\
\text { sent to the doctor's } \\
\text { app. The participants }\end{array}$ & $\begin{array}{l}\text { The findings } \\
\text { suggest that there } \\
\text { was significant } \\
\text { improvement in } \\
\text { care among the } \\
\text { mHealth } \\
\text { intervention group } \\
\text { which improved } \\
\text { the level of } \\
\text { compliance. }\end{array}$ \\
\hline
\end{tabular}




\begin{tabular}{|c|c|c|c|c|c|c|c|}
\hline & & & & & & \begin{tabular}{|l}
\multicolumn{3}{|c|}{ were divided into two } \\
groups, mhealth \\
intervention group \\
and the control group
\end{tabular} & \\
\hline [26] & 2016 & $\begin{array}{l}\text { United } \\
\text { States }\end{array}$ & RCT & Physical activity & $\begin{array}{l}30 \text { pregnant } \\
\text { women were } \\
\text { included in the } \\
\text { study. }\end{array}$ & $\begin{array}{l}\text { The study adopted a } \\
\text { combination of Fitbit } \\
\text { and a mobile } \\
\text { application track their } \\
\text { activities. Participants } \\
\text { were divided into two } \\
\text { groups, group } \\
\text { intervention group. } \\
\text { and the control group. }\end{array}$ & $\begin{array}{l}\text { The findings } \\
\text { suggest that the } \\
\text { intervention led to } \\
\text { a boost in mood } \\
\text { and energy levels }\end{array}$ \\
\hline [27] & 2016 & $\begin{array}{l}\text { United } \\
\text { States }\end{array}$ & $\begin{array}{l}\text { Observation } \\
\text { study without } \\
\text { control }\end{array}$ & $\begin{array}{l}\text { Blood pressure } \\
\text { and weight } \\
\text { management }\end{array}$ & $\begin{array}{l}8 \text { women were } \\
\text { included in the } \\
\text { study. The } \\
\text { duration of the } \\
\text { study was six } \\
\text { months. }\end{array}$ & $\begin{array}{l}\text { The study adopted the } \\
\text { use of a mobile app } \\
\text { which was connected } \\
\text { to a digital weight } \\
\text { scale and blood } \\
\text { pressure monitor. The } \\
\text { values were analysed } \\
\text { on the mobile app } \\
\text { with an alert sent to } \\
\text { patient and healthcare } \\
\text { practitioner }\end{array}$ & $\begin{array}{l}\text { The findings of the } \\
\text { study suggests that } \\
\text { alerts improved } \\
\text { monitoring of } \\
\text { pregnant women }\end{array}$ \\
\hline [28] & 2017 & $\begin{array}{l}\text { United } \\
\text { States }\end{array}$ & $\begin{array}{l}\text { Observation } \\
\text { study without } \\
\text { control }\end{array}$ & Depression & $\begin{array}{l}36 \text { women with } \\
\text { symptoms of } \\
\text { depression were } \\
\text { included in the }\end{array}$ & $\begin{array}{l}\text { The mobile app - } \\
\text { Ginger.io was } \\
\text { developed to help } \\
\text { pregnant women rate }\end{array}$ & $\begin{array}{l}\text { The findings } \\
\text { suggest that lower } \\
\text { moods were found } \\
\text { in women with }\end{array}$ \\
\hline
\end{tabular}




\begin{tabular}{|c|c|c|c|c|c|c|c|}
\hline & & & & & $\begin{array}{l}\text { study. The } \\
\text { duration of the } \\
\text { app usage was } 8 \\
\text { weeks. } \\
\text { Participants were } \\
\text { older than } 18 \\
\text { years of age }\end{array}$ & $\begin{array}{l}\text { their mood and gather } \\
\text { movement data as } \\
\text { well as mobile phone } \\
\text { usage, based on the } \\
\text { data, send } \\
\text { notifications to health } \\
\text { care providers }\end{array}$ & $\begin{array}{l}\text { higher levels of } \\
\text { travels compared } \\
\text { to women who } \\
\text { performed more } \\
\text { activities. }\end{array}$ \\
\hline [29] & 2017 & $\begin{array}{l}\text { United } \\
\text { States }\end{array}$ & $\begin{array}{l}\text { Observation } \\
\text { study without } \\
\text { control }\end{array}$ & Pregnancy risks & $\begin{array}{l}16 \text { pregnant } \\
\text { women. The app } \\
\text { was evaluated } \\
\text { within } 3 \text { months. } \\
\text { The study } \\
\text { consisted of } \\
\text { women older } \\
\text { than } 18 \text { years }\end{array}$ & $\begin{array}{l}\text { The mobile app - } \\
\text { MyHealthyPregnancy } \\
\text { was developed to help } \\
\text { pregnant women } \\
\text { make daily } \\
\text { assessment to identify } \\
\text { potential risks to } \\
\text { pregnancy }\end{array}$ & $\begin{array}{l}\text { The study found } \\
\text { that the use of the } \\
\text { app improved } \\
\text { attendance of } \\
\text { women with high } \\
\text { risk pregnancy }\end{array}$ \\
\hline [30] & 2018 & $\begin{array}{l}\text { United } \\
\text { States }\end{array}$ & RCT & Depression & $\begin{array}{l}72 \text { women took } \\
\text { part in the study. }\end{array}$ & $\begin{array}{l}\text { A mobile app - mood } \\
\text { tracking and alert was } \\
\text { adopted in this study } \\
\text { to alert healthcare } \\
\text { providers when there } \\
\text { is a decline in mood } \\
\text { of pregnant women. } \\
\text { The study had two } \\
\text { groups, } \\
\text { intervention group } \\
\text { and the control group }\end{array}$ & $\begin{array}{l}\text { The results show } \\
\text { that women who } \\
\text { used the app were } \\
\text { more likely to get } \\
\text { assistance } \\
\text { regarding mental } \\
\text { health services }\end{array}$ \\
\hline
\end{tabular}




\begin{tabular}{|c|c|c|c|c|c|c|c|}
\hline [31] & 2017 & Denmark & $\begin{array}{l}\text { Observation } \\
\text { study without } \\
\text { control }\end{array}$ & $\begin{array}{l}\text { Pre-existing } \\
\text { diabetes }\end{array}$ & $\begin{array}{l}139 \text { pregnant } \\
\text { women with pre- } \\
\text { existing diabetes } \\
\text { took part in the } \\
\text { study. }\end{array}$ & $\begin{array}{|lr|}\text { A mobile app }- \\
\text { Pregnant } & \text { with } \\
\text { Diabetes was to } \\
\text { inform women with } \\
\text { pre-existing cases of } \\
\text { diabetes }\end{array}$ & $\begin{array}{l}\text { The findings of the } \\
\text { study show that } \\
\text { the use of the app } \\
\text { improved } \\
\text { knowledge of the } \\
\text { patients on the } \\
\text { usefulness of } \\
\text { glycaemic control } \\
\text { and folic acid } \\
\text { before conception. }\end{array}$ \\
\hline [32] & 2018 & $\begin{array}{l}\text { United } \\
\text { Kingdom }\end{array}$ & RCT & $\begin{array}{l}\text { Smoking } \\
\text { cessation }\end{array}$ & $\begin{array}{l}565 \text { pregnant } \\
\text { women were } \\
\text { randomly } \\
\text { selected to take } \\
\text { part in the study. } \\
\text { Data was } \\
\text { collected over a } \\
\text { period of } 2 \text { years }\end{array}$ & $\begin{array}{l}\text { A mobile app - } \\
\text { SmokeFree Baby was } \\
\text { developed to facilitate } \\
\text { engagement with } \\
\text { pregnant women to } \\
\text { aid abstinence from } \\
\text { smoking. }\end{array}$ & $\begin{array}{l}\text { The findings } \\
\text { suggests that the } \\
\text { use of the app did } \\
\text { not aid smoking } \\
\text { abstinence during } \\
\text { pregnancy }\end{array}$ \\
\hline [33] & 2018 & Norway & RCT & $\begin{array}{l}\text { Gestational } \\
\text { mellitus }\end{array}$ & $\begin{array}{l}17 \text { pregnant } \\
\text { women with } \\
\text { gestational } \\
\text { diabetes took } \\
\text { part in this study }\end{array}$ & $\begin{array}{l}\text { A mobile app - } \\
\text { Pregnancy }+ \text { was } \\
\text { evaluated to } \\
\text { determine whether } \\
\text { pregnant women with } \\
\text { gestational diabetes } \\
\text { could manage their } \\
\text { health. Participants } \\
\text { were divided into two } \\
\text { groups, intervention }\end{array}$ & $\begin{array}{l}\text { The findings } \\
\text { suggest that } \\
\text { technical } \\
\text { problems } \\
\text { hampered the use } \\
\text { of the app, } \\
\text { although useful } \\
\text { information was } \\
\text { provided through } \\
\text { the app. }\end{array}$ \\
\hline
\end{tabular}




\begin{tabular}{|c|c|c|c|c|c|c|c|}
\hline & & & & & & $\begin{array}{lll}\text { group and control } \\
\text { group }\end{array}$ & \\
\hline$[34]$ & 2017 & Australia & RCT & $\begin{array}{l}\text { Nutrition and } \\
\text { physical activity }\end{array}$ & $\begin{array}{l}162 \text { women took } \\
\text { part in the study. }\end{array}$ & $\begin{array}{l}\text { A mobile app was } \\
\text { evaluated by pregnant } \\
\text { women to support } \\
\text { nutrition and physical } \\
\text { activity. The } \\
\text { participants were } \\
\text { divided into two } \\
\text { groups, intervention } \\
\text { and control group. }\end{array}$ & $\begin{array}{l}\text { The findings } \\
\text { suggests that there } \\
\text { is no improvement } \\
\text { in the use of the } \\
\text { app with regards } \\
\text { to the healthy } \\
\text { eating index, } \\
\text { however, healthy } \\
\text { diets was noticed } \\
\text { across different } \\
\text { groups }\end{array}$ \\
\hline$[35]$ & 2018 & Ireland & RCT & $\begin{array}{l}\text { Gestational } \\
\text { diabetes }\end{array}$ & $\begin{array}{l}565 \text { women took } \\
\text { part in the study. } \\
\text { Datar was } \\
\text { collected within } \\
3 \text { years }\end{array}$ & $\begin{array}{l}\text { A mobile app was } \\
\text { evaluated by pregnant } \\
\text { women which gave } \\
\text { them access to } \\
\text { healthy recipes as } \\
\text { well as exercise } \\
\text { options. } \\
\text { participants were } \\
\text { divided into two } \\
\text { groups, intervention } \\
\text { and control group. }\end{array}$ & $\begin{array}{l}\text { The trial improved } \\
\text { hospital visits but } \\
\text { did not reduce the } \\
\text { incidence } \\
\text { gestational } \\
\text { diabetes. }\end{array}$ \\
\hline$[36]$ & 2018 & Switzerland & $\begin{array}{l}\text { Observation } \\
\text { study without } \\
\text { control }\end{array}$ & Blood Pressure & $\begin{array}{l}32 \text { pregnant } \\
\text { women took part } \\
\text { in the study. }\end{array}$ & $\begin{array}{l}\text { A mobile app that } \\
\text { uses an algorithm that } \\
\text { tests for blood } \\
\text { pressure }\end{array}$ & $\begin{array}{l}\text { The findings } \\
\text { suggest that there } \\
\text { were } \\
\text { overestimations }\end{array}$ \\
\hline
\end{tabular}




\begin{tabular}{|c|c|c|c|c|c|c|c|}
\hline & & & & & & $\begin{array}{l}\text { developed and } \\
\text { evaluated by pregnant } \\
\text { women. }\end{array}$ & $\begin{array}{l}\text { and } \\
\text { underestimations } \\
\text { of blood pressure } \\
\text { readings. }\end{array}$ \\
\hline \begin{tabular}{|l|l}
{$[37]$} \\
\end{tabular} & 2019 & Iran & $\begin{array}{l}\text { Observation } \\
\text { study without } \\
\text { control }\end{array}$ & Preeclampsia & $\begin{array}{l}108 \text { pregnant } \\
\text { women took part } \\
\text { in the study. Data } \\
\text { was collected } \\
\text { over a three } \\
\text { month period }\end{array}$ & $\begin{array}{l}\text { A mobile app was } \\
\text { developed and } \\
\text { evaluated by pregnant } \\
\text { women. The purpose } \\
\text { of the app was to } \\
\text { educate women on } \\
\text { preeclampsia. The } \\
\text { knowledge of women } \\
\text { were assessed before } \\
\text { and after the } \\
\text { intervention }\end{array}$ & $\begin{array}{l}\text { The findings of the } \\
\text { study showed that } \\
\text { the use of the } \\
\text { mobile application } \\
\text { increased the } \\
\text { knowledge of } \\
\text { women } \\
\text { preeclampsia. }\end{array}$ \\
\hline
\end{tabular}

Table I: Summary of the findings 


\section{Self-management mobile apps in pregnancy}

Various apps have been developed self-management of women during pregnancy. Apps such as GestAção [20] and MyHealthyPregnancy [29] were developed to help pregnant women monitor their pregnancy development and identify potential risks [29]. Apps such as Pregnancy + [33], Dnurse [25] and Pregnant with Diabetes [31]. Other mobile apps such as Foodcoach [22] and apps developed by [34] and [35] have been developed to improve the diet of pregnant women and facilitate physical activity. Apps have also been developed to enable women monitor their blood pressure and maintain a healthy weight [36], for example, Babyscript [23]. Tracking devices such as FitBit have been used together with an app to track physical activities of pregnant women [24] [26]. Various apps have also been developed to monitor the mood of pregnant women [28] [30], for example, Ginger.io [28]. Mobile apps such as SmokeFree Baby [32] have been developed to facilitate smoking cessation during pregnancy. A mobile app was also developed to educate women on preeclampsia [37].

\section{Effectiveness of self-management mobile apps in pregnancy}

The outcomes section in Table I shows the effectiveness of self-management mobile apps in pregnancy. Although the majority of the impact was directly on the health of the women, they were impacts noticed in health service delivery. For example, Borgen et al. [21] report that the use of Pregnancy+ mobile app reduced the number of caeserean birth. Moreso, there was an impact on healthcare service delivery as there were less emergency cases recorded among pregnant women. The Foodcoach app improved the cholesterol levels of women who used the app [22]. The use of FitBit with a mobile application improved the mood and energy levels of pregnant women [26]. The use of self-management apps during pregnancy reduced inpatient visits [23] and the level of compliance [25] in some cases, while in other cases, the use of self-management mobile apps also improved hospital visits [35], especially for patients with high risk pregnancy [29]. Improved knowledge and awareness on matters relating to pregnancy have been highlighted as key outcomes of using mobile apps for self-management during pregnancy [20] [24] [31] [37], hence, leading to behavioural change. The use of mobile apps during pregnancy have also helped women in better health monitoring [27]. Women who used mobile apps to track their moods during pregnancy improved their chances of receiving mental health treatment [30]. The use of mobile mobile apps for self-management improved healthy diet of pregnant women [34].

Mobile apps during pregnancy, however, did not improve smoking cessation [32] and can also lead to inaccuracies such as overestimations and underestimations of blood pressure readings [36]. The use of self-management mobile apps during pregnancy did not reduce the incidence of gestational diabetes [35]. Furthermore, 
technical issues can hamper the the effective use of mobile apps for self-management during pregnancy [33].

Functionalities of Self-Management Mobile Apps in Pregnancy

The functionalities of the mobile apps identified in this study have been categorised as shown in Table II [19].

Table II: Functionalities of self-management mobile apps in pregnancy

\begin{tabular}{|c|c|l|c|l|l|l|l|}
\hline Authors & Inform & Instruct & Record & Dispay & Guide & $\begin{array}{l}\text { Remind/ } \\
\text { Alert }\end{array}$ & Communicate \\
\hline$[20]$ & $\checkmark$ & & $\checkmark$ & & & & \\
\hline$[21]$ & $\checkmark$ & & $\checkmark$ & & $\checkmark$ & & \\
\hline$[22]$ & & & $\checkmark$ & & $\checkmark$ & & $\checkmark$ \\
\hline$[23]$ & $\checkmark$ & & & & $\checkmark$ & & \\
\hline$[24]$ & $\checkmark$ & & & $\checkmark$ & & & \\
\hline$[25]$ & & & $\checkmark$ & $\checkmark$ & & & $\checkmark$ \\
\hline$[26]$ & & & $\checkmark$ & $\checkmark$ & & & \\
\hline$[27]$ & & & $\checkmark$ & $\checkmark$ & & $\checkmark$ & $\checkmark$ \\
\hline$[28]$ & & & $\checkmark$ & $\checkmark$ & & $\checkmark$ & $\checkmark$ \\
\hline$[29]$ & $\checkmark$ & & & & $\checkmark$ & & \\
\hline$[30]$ & & & & & & $\checkmark$ & $\checkmark$ \\
\hline$[31]$ & $\checkmark$ & & & & & & \\
\hline$[32]$ & & & & & $\checkmark$ & & \\
\hline$[33]$ & & & & & $\checkmark$ & & \\
\hline$[34]$ & & & & & $\checkmark$ & & \\
\hline$[35]$ & $\checkmark$ & & & & & & \\
\hline$[36]$ & $\checkmark$ & & $\checkmark$ & $\checkmark$ & & & \\
\hline$[37]$ & $\checkmark$ & & & & & & \\
\hline
\end{tabular}

\section{Discussion}

The purpose of this study was to systematically review and appraise the literature on mobile apps for self-management during pregnancy to identify the different selfmanagement mobile apps which have been developed and evaluated to support women during pregnancy, identify the functionalities of self-management mobile apps for pregnancy, describe the effectiveness of self-management mobile apps for pregnancy and identify the research gaps in the current literature and suggesting directions for future research. 
A narrative synthesis of the findings was presented. 18 studies were included in this study. These studies evaluated a wide range of mobile apps supporting various health domains relevant to women's health during pregnancy.

From the findings of the reviewed literature, it can be concluded that the use of mobile apps during pregnancy point towards a positive impact on pregnancy and health service delivery. Although the majority of the studies pointed towards impact on women's physcial health addressing some of the major complications in pregnancy such as gestational diabetes, preeclampsia, weight management, and high blood pressure [35] [37] [25] [27], some of the studies also focused on the psychological health of pregnant women [30]. This shows that mobile apps can help pregnant women with major complications in pregnancy improve their health conditions through self-monitoring. Some of the apps also facilitated communication with medical practitioners. This suggests that mobile apps can facilitate communication between pregnant women and medical practitioners despite the distance which is a suitable option for patients in areas with less access to medical pracitioners and medical facilities.

The apps included in this study were developed with different functionalities. Some apps were developed to inform patients about their health conditions [20] [21]. Other app functionalities include recording patients' vital signs through wearable technologies like FitBit [24] [26] and recording the information into a mobile app. Mobile apps also recorded vital signs through digital technologies [27]. This shows that mobile apps do not only inform patients but are also capable of performing complex functions relevant to improving healthcare. Some apps displayed the results of vital signs gathered from other technologies either as graphs or converted information on the graphic user interface. Some apps were developed to guide pregnant women regarding certain behaviours for example, eating behaviour and physical activities. Some apps were used to alert or remind patients while others were used to communicate with healthcare practitioners. This shows that mobile apps can perform specific functions related to improving women's health during pregnancy. The papers included in this study were published from 2016 to 2019, although the search period was from 2009 to 2019. This suggests that publication within this domain (evaluation of self-management mobile apps during pregnancy) is a relatively new area of investigation. As such, more research is needed within this domain.

Self-management apps for pregnant women with gestational diabetes allowed patients share information with their healthcare providers [25]. This is similar to the findings of Bryzan et al. [38] which suggests that mobile apps for diabetes facilitates sharing of information with medical doctors. Information sharing with healthcare providers provide an opportunity to make decisions about the patient at distant 
locations. There is a great need for self-management during pregnancy as this could help reduce complications related to pregnancy and childbirth.

\section{Directions for future research}

While there were many health domains which have been trialed in the literature such as depression, gestational diabetes/mellitus, nutrition and physical activity, weight gain and weight management, there was a dearth of studies focusing on complications such as identification of sexually transmitted infections, early warning signs of potential still birth, miscarriage and management of anaemia during pregnancy.

There was a plethora of apps identified relating to blood pressure monitoring; however, inaccuracies in the results were identified, it was then suggested that mHealth apps for health should be trialed before they are uploaded to the App store [36]. Although, apps included in this study have various functionalities, there was a dearth of apps developed mainly to instruct patients. According to Aitken and Gauntlett [19], healthcare apps can also "provide instructions to the users". This is similar to the findings of Jeddi et al. [39] which suggests that functionalities of selfmanagement technologies for chronic kidney disease are not focused on instructing users. Future research should focus on developing mobile apps to support pregnant women by giving them instructions on how to perform certain activities.

There was a lack of studies investigating the usability of mobile apps for selfmanagement in pregnancy. It would be interesting to see how pregnant women use these apps and the challenges experienced. This will help developers improve the design of mobile apps for self-management during pregnancy.

There was a lack of longtitudinal studies exploring the effect of long term use of mobile apps for self-management during pregnancy. It would be interesting to see how mobile apps can impact on the health of pregnant women on the long run.

Among the 18 studies reviewed, only two studies were conducted in developing countries, China and Iran. Other studies were conducted in developed countries, with the majority focusing on the United States and Norway. This calls for more research focusing on the development and evaluation of mobile apps for self-management during pregnancy especially in developing countries where there is a high rate of maternal maternity [1].

\section{Strengths and limitations}

While the objectives of this study were met, this study was limited in several ways. As a result of the search strategy used as well as the inclusion and exclusion criteria, we might have missed important papers relating to the evaluation of mobile apps for self-management in pregnancy. We also excluded studies not published in English and the search period was for a period of ten years, as such, we might have missed 
important papers on the subject. However, to improve the reliability of the paper selection process, two authors independently reviewed the papers before deciding which papers to be included in the study.

\section{Conclusion}

This paper provided a review of mobile apps for self-management in pregnancy. The results reveal the effectiveness of mobile apps for self-management during pregnancy. Mobile apps for self-management during pregnancy have been evaluated in different countries with one evaluation conducted in Iran, a developing country. The review also highlighted the functionalities of these apps, limitations and directions for future research.

\section{Compliance with Ethical Standards}

Conflict of Interest: Author GEI declares that she has no conflict of interest. Author ARD declares that he has no conflict of interest. Author VV declares that she has no conflict of interest. Author MI declares that she has no conflict of interest.

Ethical approval: This article does not contain any studies with human participants or animals performed by any of the authors.

\section{References}

1. United Nations Children's Funds. (2019). Maternal Mortality. https://data.unicef.org/topic/maternal-health/maternal-mortality/ (accessed on 10 January 2020).

2. Ghodke B, Pusukuru R, Mehta, V. (2017). Association of lipid profile in pregnancy with preeclampsia, gestational diabetes mellitus, and preterm delivery. Cureus, 9(7). https:// 10.7759/cureus.1420

3. World Health Organisation. (2019). Maternal Mortality. https://www.who.int/news-room/fact-sheets/detail/maternal-mortality (accessed on 10 January 2020).

4. Lorig KR, Holman HR (2003). Self-management education: history, definition, outcomes, and mechanisms. Annals of Behavioral Medicine, 26(1), 1-7. https//10.1207/S15324796ABM2601_01

5. Iyawa GE, Herselman M, Botha A. (2016). Digital health innovation ecosystems: From systematic literature review to conceptual framework. Procedia Computer Science, 100, 244-252. https://doi.org/10.1016/j.procs.2016.09.149 
6. Iyawa, G, Botha A, Herselman, M (2016). Identifying and defining the terms and elements related to a digital health innovation ecosystem. In: Herselman M, Botha A (ed). Strategies, Approaches and Experiences: Towards building a South African Digital Health Innovation Ecosystem, CSIR, Pretoria, 30-58.

7. Iyawa GE, Langan-Martin J, Sevalie S, Masikara W. (2020). mHealth as tools for development in mental health. In: In McHaney, W, Reychev, I, Azuri, J, McHaney, ME, Moshonov (ed). Impacts of Information Technology on Patient Care and Empowerment, Hershey, IGI Global, 5880 .

8. Stankevich E, Paramonov I, Timofeev I. (2012, November). Mobile phone sensors in health applications. In 2012 12th Conference of Open Innovations Association (FRUCT) (pp. 1-6). IEEE.

9. Statland JM, Wang Y, Richesson R, Bundy B, Herbelin L, Gomes J, Trivedi J, Venance SL, Amato AA, Hanna MG, Griggs RC, Barohn RJ, and the CINCH Consortium. (2011). An interactive voice response diary for patients with non-dystrophic myotonia. Muscle Nerve, 44, 3035,

10. Huckvale K, Car M, Morrison C, Car J. (2012). Apps for asthma selfmanagement: a systematic assessment of content and tools. BMC medicine, 10(1), 144.

11. Arnhold M, Quade M, Kirch W. (2014). Mobile applications for diabetics: a systematic review and expert-based usability evaluation considering the special requirements of diabetes patients age 50 years or older. Journal of medical Internet research, 16(4), e104.

12. Balsam J, Ossandon M, Bruck HA, Lubensky I, Rasooly A. (2013). Low-cost technologies for medical diagnostics in low-resource settings. Expert Opinion on Medical Diagnostics, 7(3), 243-255.

13. Coorey GM, Neubeck L, Mulley J, Redfern J. (2018). Effectiveness, acceptability and usefulness of mobile applications for cardiovascular disease self-management: Systematic review with meta-synthesis of quantitative and qualitative data. European Journal of Preventive Cardiology, 25(5), 505-521.

14. Whitehead L, Seaton P (2016). The effectiveness of self-management mobile phone and tablet apps in long-term condition management: a systematic review. Journal of Medical Internet Research, 18(5), e97. 
15. Chan KL, Chen M. (2019). Effects of social media and mobile health apps on pregnancy care: meta-analysis. JMIR mHealth and uHealth, 7(1), e11836.

16. Amoakoh-Coleman, M, Borgstein ABJ, Sondaal SF, Grobbee DE, Miltenburg AS, Verwijs M, Klipstein-Grobusch K. (2016). Effectiveness of mHealth interventions targeting health care workers to improve pregnancy outcomes in low-and middle-income countries: a systematic review. Journal of medical Internet research, 18(8), e226.

17. Moher D, Liberati A, Tetzlaff J, Altman DG, The PRISMA Group (2009). Preferred Reporting Items for Systematic Reviews and MetaAnalyses: The PRISMA Statement. PLoS Med 6(7): e1000097. doi:10.1371/journal.pmed1000097

18. Kaushal R, Shojania KG, Bates DW. (2003). Effects of computerized physician order entry and clinical decision support systems on medication safety: a systematic review. Archives of Internal Medicine, 163(12), 14091416.

19. Aitken M, \& Gauntlett C. (2013). Patient apps for improved healthcare from novelty to mainstream.

20. Silva RMD, Brasil CCP, Bezerra IC, Queiroz FFDSN. (2019). Mobile health technology for gestational care: evaluation of the GestAção's app. Revista Brasileira de Enfermagem, 72, 266-273.

21. Borgen I, Småstuen MC, Jacobsen AF, Garnweidner-Holme, LM., Fayyad, S, Noll, J, Lukasse, M. (2019). Effect of the Pregnant+ smartphone application in women with gestational diabetes mellitus: a randomised controlled trial in Norway. BMJ Open, $9(11)$.

22. Li, LJ, Aris, IM, Han, WM, Tan KH. (2019). A Promising FoodCoaching Intervention Program to Achieve Optimal Gestational Weight Gain in Overweight and Obese Pregnant Women: Pilot Randomized Controlled Trial of a Smartphone App. JMIR Formative Research, 3(4), e13013.

23. Marko KI, Ganju N, Krapf JM, Gaba ND, Brown JA, Benham JJ, Meltzer AC. (2019). A Mobile Prenatal Care App to Reduce In-Person Visits: Prospective Controlled Trial. JMIR mHealth and uHealth, 7(5), e10520. 
24. Kominiarek MA, Vyhmeister H, Balmert LC, Fairchild P, Tolo H, Grobman W, Simon M. (2018). Activity tracking devices in group prenatal care: A feasibility study. BioResearch Open Access, 7(1), 165-176.

25. Guo H, Zhang Y, Li P, Zhou P, Chen LM, Li, SY. (2019). Evaluating the effects of mobile health intervention on weight management, glycemic control and pregnancy outcomes in patients with gestational diabetes mellitus. Journal of Endocrinological Investigation, 42(6), 709-714.

26. Choi J, Hyeon L, Lee J, Vittinghoff E, Fukuoka Y. (2016). mHealth physical activity intervention: a randomized pilot study in physically inactive pregnant women. Maternal and Child Health Journal, 20(5), 10911101.

27. Marko, K. I., Krapf, J. M., Meltzer, A. C., Oh, J., Ganju, N., Martinez, A. G., ... \& Gaba, N. D. (2016). Testing the feasibility of remote patient monitoring in prenatal care using a mobile app and connected devices: a prospective observational trial. JMIR research protocols, 5(4), e200.

28. Faherty LJ, Hantsoo L, Appleby D, Sammel MD, Bennett IM, Wiebe DJ. (2017). Movement patterns in women at risk for perinatal depression: Use of a mood-monitoring mobile application in pregnancy. Journal of the American Medical Informatics Association, 24(4), 746-753.

29. Krishnamurti T, Davis AL, Wong-Parodi G, Fischhoff B, Sadovsky Y, Simhan HN. (2017). Development and testing of the Myhealthypregnancy app: a behavioral decision research-based tool for assessing and communicating pregnancy risk. JMIR mHealth and uHealth, 5(4), e42.

30. Hantsoo L, Criniti S, Khan A, Moseley, M, Kincler N, Faherty LJ, Bennett IM. (2017). A mobile application for monitoring and management of depressed mood in a vulnerable pregnant population. Psychiatric Services, 69(1), 104-107.

31. Nørgaard SK, Nichum VL, Barfred C, Juul HM, Secher AL, Ringholm L, Mathiesen ER. (2017). Use of the smartphone application" Pregnant with Diabetes". Danish Medical Journal, 64(11).

32. Tombor I, Beard E, Brown J, Shahab L, Michie S, West R. (2018). Randomized factorial experiment of components of the SmokeFree Baby smartphone application to aid smoking cessation in pregnancy. Translational Behavioral Medicine. 9(4), 583-593.

33. Skar JB, Garnweidner-Holme LM, Lukasse M, Terragni L. (2018). Women's experiences with using a smartphone app (the Pregnant+ app) to 
manage gestational diabetes mellitus in a randomised controlled trial. Midwifery, 58, 102-108.

34. Dodd JM, Louise J, Cramp C, Grivell RM, Moran LJ, Deussen AR. (2018). Evaluation of a smartphone nutrition and physical activity application to provide lifestyle advice to pregnant women: The SNAPP randomised trial. Maternal \& Child Nutrition, 14(1), e12502.

35. Kennelly MA, Ainscough K, Lindsay KL, O'Sullivan E, Gibney ER, McCarthy M, Hatunic M. (2018). Pregnancy Exercise and Nutrition with Smartphone Application Support: A Randomized Controlled Trial. Obstetrics \& Gynecology, 131(5), 818-826.

36. Raichle CJ, Eckstein J, Lapaire O, Leonardi L, Brasier N, Vischer AS, Burkard T. (2018). Performance of a blood pressure smartphone app in pregnant women: the iPARR Trial (iPhone app compared with standard RR measurement). Hypertension, 71(6), 1164-1169.

37. Parsa S, Khajouei R, Baneshi MR, Aali BS. (2019). Improving the knowledge of pregnant women using a pre-eclampsia app: A controlled before and after study. International Journal of Medical Informatics, 125, 86-90.

38. Brzan PP, Rotman E, Pajnkihar M, Klanjsek P. (2016). Mobile applications for control and self management of diabetes: a systematic review. Journal of Medical Systems, 40(9), 210.

39. Jeddi FR, Nabovati E, Amirazodi S. (2017). Features and effects of information technology-based interventions to improve self-management in chronic kidney disease patients: a systematic review of the literature. Journal of Medical Systems, 41(11), 170.

\section{Appendix 1}

Search Strategy

\begin{tabular}{clc}
\hline Database & \multicolumn{2}{c}{ Strategy } \\
\hline & \multicolumn{1}{c}{$(((($ "pregnant"[Title/Abstract] OR "antenatal"[Title/Abstract] OR "prenatal"[Ti } \\
& OR "expecting"[Title/Abstract])) AND ("mobile phone"[Title/Abst \\
"mhealth"[Title/Abstract] OR "m-health"[Title/Abstract] OR "mHealth"[Title/Abstr & \\
PubMed & Health"[Title/Abstract] OR "mobile health"[Title/Abstract] OR "smartphone"[Title/A \\
& "mobile app"[Title/Abstract] OR "mobile application"[Title/Abstract])) AND ("2 \\
& Publication]: "2019"[Date - Publication]))
\end{tabular}


(("pregnant" OR "pregnancy" OR "antenatal" OR "prenatal" OR "expecting") AI $\begin{array}{ll}\text { Scopus } & \text { phone" OR "mhealth" OR mhealth "OR " m-health " OR " m } \\ & \text { smartphone "OR " mobile AND app " OR " mobile AND application)) }\end{array}$

("pregnant" OR "pregnancy" OR "antenatal" OR "prenatal" OR "expecting") - Ti AND ("mobile phone" OR "mhealth" OR mhealth " OR " m-healt

CINAHL " mobile AND health" OR " smartphone" OR " mobile AND ap

" mobile AND application) - Title

("pregnant" OR "pregnancy" OR "antenatal" OR "prenatal" OR "expecting") - T AND ("mobile phone" OR "mhealth" OR mhealth " OR " m-heal

EMBASE " mobile AND health" OR " smartphone" OR " mobile AND ap

" mobile AND application) - Title/Abstract 